九州大学学術情報リポジトリ

Kyushu University Institutional Repository

\title{
China's Agricultural Trade Costs : Measurement and Determinants
}

Wang, Xuejun

College of Economics and Management, Nanjing Agricultural University

Han, Guizhi

College of Economics and Management, Nanjing Agricultural University

Maeda, Koshi

Laboratory of Quantitative Food Economic Analysis, Division of Agricultural and Resource

Economics, Department of Agricultural and Resource Economics, Faculty of Agriculture, Kyushu University

Zhou, Yingheng

College of Economics and Management, Nanjing Agricultural University

https://doi.org/10.5109/1564105

出版情報：九州大学大学院農学研究院紀要. 61 (1)，pp. 215-223，2016-02-29. Faculty of Agriculture, Kyushu University

バージョン :

権利関係 : 


\title{
China's Agricultural Trade Costs: Measurement and Determinants
}

\author{
Xuejun WANG ${ }^{1}$, Guizhi HAN ${ }^{1}$, Koshi MAEDA and Yingheng ZHOU ${ }^{1 *}$
}

\author{
Laboratory of Quantitative Food Economic Analysis, Division of Agricultural and \\ Resource Economics, Department of Agricultural and Resource Economics, \\ Faculty of Agriculture, Kyushu University, Fukuoka 812-8581, Japan \\ (Received November 10, 2015 and accepted November 19, 2015)
}

\begin{abstract}
Trade costs involve important implications that partly determine a country's ability to integrate itself into a global trading system. The major purposes of this study are to analyze China's agricultural trade costs and the determinants of these costs. A micro-founded measure of trade frictions developed by Novy (2011) is applied to estimate an indirect measure of China's agricultural trade costs with a large cross-section dataset of its trading partners. The results show that China's agricultural trade costs experienced only a modest downward trend from 1995 to 2011. The weighted average tariff equivalent of trade costs is 141 percent in 2011, which is far higher than the world average. Statistical analyses of the determinants of China's agricultural trade costs suggest that geographical and cultural factors explain most of the trade costs variation, whereas participation in multilateral and bilateral trade agreements do not appear to be an important determinant. In addition, the trade cost measure shows substantial differences in the levels of integration across sectors and trading partners.
\end{abstract}

Key words: Agriculture, China, Gravity, Trade costs

\section{INTRODUCTION}

International trade costs are important for theory and in practice ${ }^{1}$. Obstfeld and Rogoff (2000) make the point that all major puzzles of international macroeconomics hinge on trade costs. Anderson and Wincoop (2004) argue that trade costs are richly linked to economic policy and have large welfare implications. Additionally, trade liberalization across the world has greatly reduced the average level of traditional tariff and non-tariff barriers to trade. However, the general conclusion of recent empirical investigations is that trade costs continue to exist and are much larger than expected. (Anderson and Wincoop, 2004; Olper and Raimondi, 2009; Duan and Grant, 2012; Novy, 2011).

In recent years, China has pursued export-oriented economic policies and experienced a sharp increase in trade with the rest of the world. In particular, China's accession to the WTO was an important step in facilitating its integration into the global economy. At the same time, China was engaging in a multipronged campaign to sign free trade agreements (FTAs) ${ }^{2}$. Trade policy barriers such as tariffs and non-tariff trade barriers facing Chinese firms exporting to other countries have undoubtedly declined through a series of multilateral and bilateral negotiations. A large empirical body of literature has shown that China's average trade costs have experienced substantial declines since its trade policy reforms (Shi, 2008; Fang et al., 2010; Xu and Liang, 2010). This evidence, however, applies at the aggregated level rather than to the specific industry level, and it is well known that trade costs vary widely across coun-

\footnotetext{
1 College of Economics and Management, Nanjing Agricultural University, Nanjing 210095, China

* Corresponding author (E-mail: zhouyh@njau.edu.cn)
}

tries and sectors (Anderson and Wincoop, 2004; Olper and Raimondi, 2009). We cannot conclude that similar declines in China's trade costs also exist in more disaggregated sectors, such as the agricultural sector, where special and differential treatments are accepted in the multilateral and bilateral trade agreements. Xu et al. (2012) and Wen et al. (2013) made progress in their analysis of China's trade costs for tradable goods in agriculture. As these studies typically include only a few countries, the evidence is quite scant and does not offer a clear picture of the main patterns in China's agricultural trade costs.

Whether China's agriculture has experienced substantial declines in trade costs, the significance of the remaining barriers are, and the determinants of trade costs represent important issues that must be addressed to better understand what factors are hindering China's agricultural integration into the global trading system. However, we have little direct information on the magnitude of the trade costs and only limited evidence of the determinants of these costs.

To shed light on these questions, we organize the remainder of the paper as follows. In Section 2, we estimate China's agricultural bilateral trade costs with its more comprehensive trading partners. In consideration of the heterogeneity existing in bilateral trade costs, China's aggregate agricultural export sector is further decomposed into primary and processed agricultural sectors, and their trading partners are grouped into

\footnotetext{
${ }^{1}$ In this paper, trade costs is broadly defined according to Anderson and Wincoop (2004) that include all costs incurred in getting a good to a final user other than the marginal cost of producing the good itself.

2 Currently, China has 19 Free Trade Agreements (FTAs) under construction, among which 14 Agreements have been signed and implemented already.
} 
developed and developing countries, respectively. In Section 3, we explain the variations in trade costs by relating the variations to observable trade cost proxies. These trade cost proxies include geographical factors, cultural linkages and institutional factors. We also explore whether China's participation in multilateral trade agreements promotes the integration of the country's agriculture into the global trading system. In the last section, we discuss our findings and conclude the paper.

\section{MEASURING CHINA'S AGRICULTURAL BILATERAL TRADE COSTS}

\section{Model description}

Direct methods to measure barriers to international trade are best but not always feasible due to data limitations and the enormity of the resulting datasets. The general measure indirectly infers bilateral trade costs relative to domestic trade costs from trade data based on the gravity equation. The measure is parsimonious as a data requirement and relatively simple to implement empirically. The model, which was recently developed by Novy (2011), is being widely adapted to indirectly measure bilateral trade costs (e.g., Duan and Grant, 2012; Xu et al., 2012; Jacks. et al., 2011 and Wen et al. 2013). The model is appealing because it has a strong theoretical foundation and is consistent with a large variety of leading international trade models such as Ricardian and heterogeneous firms models. Moreover, this method does not rely on any particular trade cost function, and it does not impose trade cost symmetry. In this paper, we also use the approach developed by Novy (2011) to estimate the relative trade cost measure of China's agricultural products.

Novy (2011) derived the micro-founded measure of bilateral trade costs from the Anderson and Wincoop (2003) gravity equation:

$$
x_{i j}=\frac{y_{i} y_{j}}{y^{W}}\left(\frac{t_{i j}}{\Pi_{i} \mathrm{P}_{j}}\right)^{1-\sigma}
$$

where $x_{i j}$ denotes nominal exports from country $i$ to country $j, y_{i}$ and $y_{j}$ are nominal incomes of countries $i$ and $j$, and $y^{W}$ is world income defined as $y^{W}=\sum_{k} y_{k} . \quad \sigma>1$ is the elasticity of substitution across goods. $t_{i j}$ is the bilateral trade cost measure, $\Pi_{i}$ is the outward multilateral resistance of country $i$, and $P_{j}$ is the inward multilateral resistance of country $j$.

Following Head and Ries (2001) to eliminate the multilateral resistance variables from the gravity equation, the counterpart of equation (1) for intra-national trade of country $i$ is expressed as

$$
x_{i j}=\frac{y_{i} y_{i}}{y^{W}}\left(\frac{t_{i j}}{\prod_{i} \mathrm{P}_{i}}\right)^{1-\sigma}
$$

Further, equation (2) is rewritten as

$$
\Pi_{i} P_{i}=\left(\frac{x_{i i} / y_{i}}{y_{i} / y^{W}}\right)^{\frac{1}{\sigma-1}} t_{i j}
$$

which solves for country i's outward and inward multi- lateral resistance.

When equation (1) is multiplied by the corresponding gravity equation for trade flows in the opposite direction $x_{j i}$, we obtain

$$
x_{i j} x_{j i}=\left(\frac{y_{i} y_{j}}{y^{W}}\right)^{2}\left(\frac{t_{i j} t_{j i}}{\prod_{i} \mathrm{P}_{i} \Pi_{j} \mathrm{P}_{j}}\right)^{1-\sigma}
$$

Substituting the solution from equation (3) to eliminate these multilateral resistance indices and rearranging the yields, we obtain

$$
\frac{x_{i j} x_{j i}}{x_{i i} x_{j j}}=\left(\frac{t_{i j} t_{j i}}{t_{i i} t_{j j}}\right)^{1-\sigma}
$$

Finally, taking the square root to form the geometric average and subtracting one yields the resulting expression for the tariff equivalent

$$
\tau_{i j}=\left(\frac{t_{i j} t_{j i}}{t_{i i} t_{j j}}\right)^{\frac{1}{2}}-1=\left(\frac{x_{i i} x_{j j}}{x_{i j} x_{j i}}\right)^{\frac{1}{2(\sigma-1)}}-1
$$

where $\tau_{i j}$ is the trade cost measure that captures bilateral trade costs relative to domestic trade costs.

The interpretation of the trade cost measure is straightforward. If bilateral trade flows $x_{i j} x_{j i}$ increase relative to domestic trade flows $x_{i i} x_{j j}$, it must have become easier for the two countries to trade with each other relative to trading domestically. This is captured by a decrease in $\tau_{i j}$, and vice versa.

\section{Data and parameters}

Equation (6) is applied to calculate China's agricultural trade costs with its major trading partners over a long period. To conduct this calculation, the needed data primarily involve the bilateral and intra-national agricultural trade data for China and its trading partners. The intra-national trade data $x_{i i}$ are not directly available but can be expressed as total agricultural production minus total agricultural exports, following the approach by Wei (1996) and Novy (2011).

Bilateral trade, total production and total exports are obtained from the OECD's Trade in Value Added (TiVA) dataset jointly developed by the WTO and the OECD. The latest version of the database covers 61 countries/regions and 37 industries for the years 1995, 2000, 2005, 2008, 2009, 2010 and 2011. The industry classification used in the current TiVA database is based on the International Standard Industrial Classification (ISIC, Rev. 3), which permits a clean delineation of primary agricultural products (ISIC 1,2 and 5: agriculture, hunting, forestry and fishing) and processed agricultural products (ISIC 15 and 16: food products, beverages and tobacco). The International Monetary Fund's development classification is used to categorize countries as developed or developing countries. Out of 61 countries/ regions, there are 38 developed countries/regions and 23 developing countries/regions ${ }^{3}$. The countries/regions included in our analysis represent a significant portion of China's trading partners in agriculture. These 60 countries, except China, account for approximately 82.80 percent of China's total exports of primary agricultural products and 91.51 percent of China's total exports of 
processed agricultural products during the sample period.

The choice of parameter assumption related to the elasticity of substitution $\sigma$ is a main problem in calculating trade costs using equation (6). The survey by Anderson and van Wincoop (2004) estimates $\sigma$ and conclude that it typically falls in the range $(5,10)$. Jacks et al. (2011) indicate that although the level of inferred trade costs is sensitive to the assumed parameter value, their changes over time, as well as their determinants, are largely unaffected by the parameter setting. In this study, following Anderson and van Wincoop (2004) and Novy (2011), we set the value of $\sigma$ at eight for agricultural trade.

\section{Measurement results}

Figure 1 illustrates the indirect trade cost measures for China's aggregate agriculture with its 60 trading partners over the sample period of 1995-2011, with elasticity of substitution values set at eight $(\sigma=8)^{4}$. The measure is expressed as the trade-weighted average tariff equivalent, which is an average of its bilateral trade costs weighted by the amount of trade with each trading partner. Figure 1 shows that China's export of agricultural products experienced a modest downward trend in trade costs. More specifically, the tariff equivalent of China's agricultural trade cost was 155 percent in 1995 and fell to 141 percent in 2011, with a reduction of 9 percent. China's accession into the WTO facilitates its integration into the global economy; however, there is no clear declining trend in trade costs with respect to China's agricultural product exports. Duan and Grant (2012), using the same methodology as that used in this paper, document a 2010 tariff equivalent of trade costs for global agricultural trade at 118 percent, which is far lower than that for China. This suggests that China has considerable scope for further improving its foreign trade environment. Our findings are comparable with the recent work by Wen et al. (2013). They found that China's agricultural trade costs with its five major trading partners have not exhibited a pronounced downward trend between 1995 and $2007^{5}$. Both the levels and the percentage changes in China's relative bilateral trade costs for non-agricultural products are quite different. For example, the measure for non-agriculture stands at 99 percent in the year 2011, far lower than the measure for agriculture. The trade-weighted average of China's relative trade cost measure for non-agriculture declined by 16 percent, which corresponds to an annual decline of 1.1 percent per year.

\section{Agriculture vs Non-agriculture}

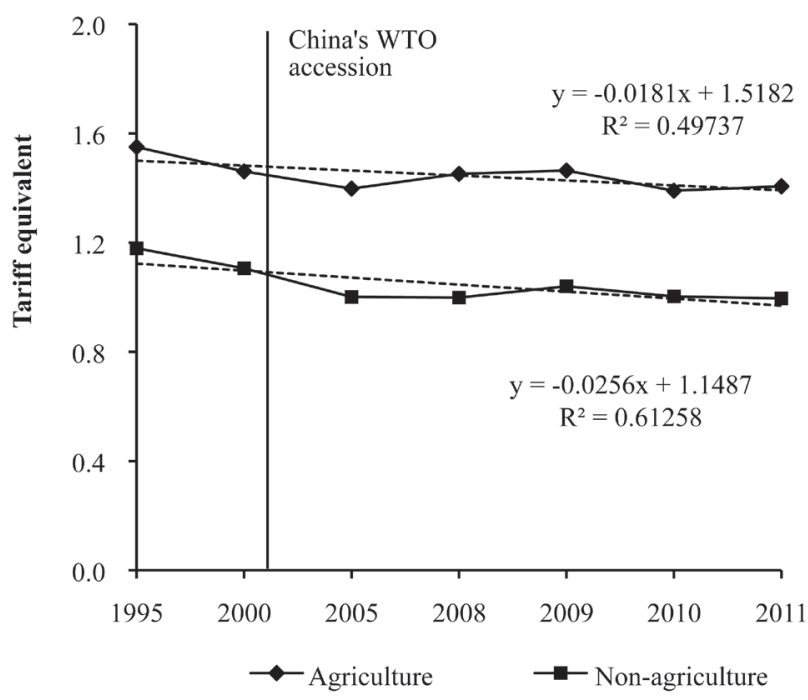

Fig. 1. Weighted average tariff equivalent of trade costs as measured for China's agricultural and non -agricultural products.

Cost heterogeneity in bilateral trade clearly emerges in Figure 2, as we compare the average bilateral trade costs of primary agriculture with those of processed agriculture from 1995 to 2011. The values of the tariff equivalent of primary agriculture in the sample period range from 166 percent to 175 percent, which is significantly higher than those for processed agriculture (133 percent to 141 percent). This implies that China's exports of primary agricultural products face higher trade barriers than those of its processed agricultural products when entering global markets. Furthermore, two types of agricultural products display less time variation in trade costs. The value of the trade cost for primary agriculture is 175 percent in 1995 and reaches 166 percent in 2011, with a reduction of 5 percent. For processed agriculture, the values change from 141 percent in 1995 to 133 percent in 2011, corresponding to a 6 percent reduction.

In Figure 3, we compare China's trade cost patterns with developed and developing trading partners. Three graphs in Figure 3 are plotted, one for aggregate agricul-

The 38 developed countries/regions include Australia (AUS), Austria (AUT), Belgium (BEL), Brunei Darussalam (BRN), Canada (CAN), Chinese Taipei (TWN), Croatia (HRV), Cyprus (CYP), Czech Republic (CZE), Denmark (DNK), Estonia (EST), Finland (FIN), France (FRA), Greece (GRC), Hong Kong, China (HKG), Germany (DEU), Hungary (HUN), Iceland (ISL), Ireland (IRL), Israel (ISR), Italy (ITA), Japan (JPN), Korea (KOR), Luxembourg (LUX), Malta (MLT), Netherlands (NLD), New Zealand (NZL), Norway (NOR), Portugal (PRT), Saudi Arabia (SAU), Singapore (SGP), Slovak Republic (SVK), Slovenia (SVN), Spain (ESP), Sweden (SWE), Switzerland (CHE), United Kingdom (GBR) and United States (USA). The 23 developing countries/regions include Argentina (ARG), Brazil (BRA), Bulgaria (BGR), Chile (CHL), Cambodia (KHM), China (CHN), Columbia (COL), Costa Rica (CRI), India (IND), Indonesia (IDN), Latvia (LVA), Lithuania (LTU), Malaysia (MYS), Philippines (PHL), Poland (POL), Romania (ROU), Russia (RUS), Turkey (TUR), South Africa (ZAF), Thailand (THA), Tunisia (TUN), Viet Nam (VNM) and Mexico (MEX).

${ }^{4}$ We also calculate the measure for elasticity of substitution values of five $(\sigma=5)$ and ten $(\sigma=10)$. The estimated trade costs vary greatly under different values of $\sigma$, but the changing trend remains the same.

${ }^{5}$ We cannot compare directly our figures and those from Wen et al. (2013) because they used China-USA 1995 trade cost as the base period and 100 as the base value and do not directly show the value of the trade cost measure. 
Primary vs Processed

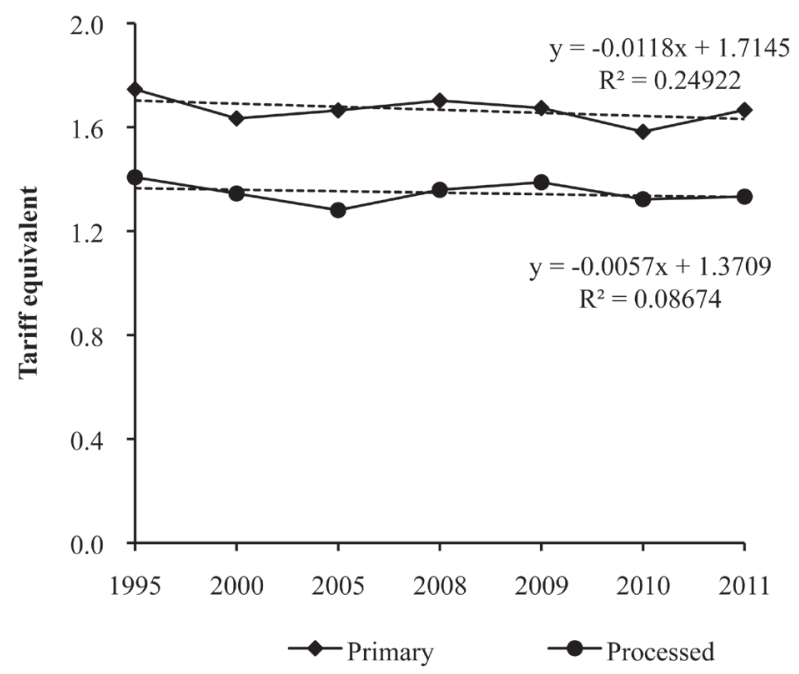

Fig. 2. Weighted average tariff equivalent of China's agricultural trade costs across sectors.

tural products, one for primary agricultural products and one depicting trade costs for processed agricultural products. First, China faces higher trade costs in its exporting of aggregate agricultural products to developing countries/regions than when exporting to developed countries. However, the gap narrows to 7 percent in 2011 from 21 percent in 1995 . The trade costs facing China's agricultural exports to developing trading part- ners experience a clear downward trend. The measure falls to 149 percent in 2011 from 175 percent in 1995, which translates to a loss of nearly 15 percent. This significant reduction is due largely to the relationship between China's primary agricultural exports and China's developing trading partners. From 1995-2011, the measures fall very rapidly as evidenced by a reduction of approximately 25 percent, specifically from 200 percent in 1995 to 150 percent in 2011. However, other trade cost relations did not display any discernible time pattern. It is interesting to note that the trade cost measure shows a substantial difference in the levels of integration across sectors and trading partner groups. From 1995-2011, China faced stronger protection in its primary agricultural exports to developed countries/ regions while encountering more trade barriers of processed agriculture from developing countries/regions.

Table A1 provides the values of the tariff equivalent $\tau_{i j}$ between China and each of its trading partners between 1995 and 2011. Not surprisingly, the trade cost measure varies considerably across countries/regions. As indicated in the table, the values for China's aggregate agriculture in 2011 range from a lower value of 97 percent for Hong Kong to a higher value of 447 percent for Malta, with a median value of 199 percent; for primary agriculture, the values range from 118 percent for Thailand to 571 percent for Malta, with a median value of 226 percent; for processed agriculture, the values range from 89 percent for Hong Kong to 403 percent for Malta, with a median value of 178 percent.
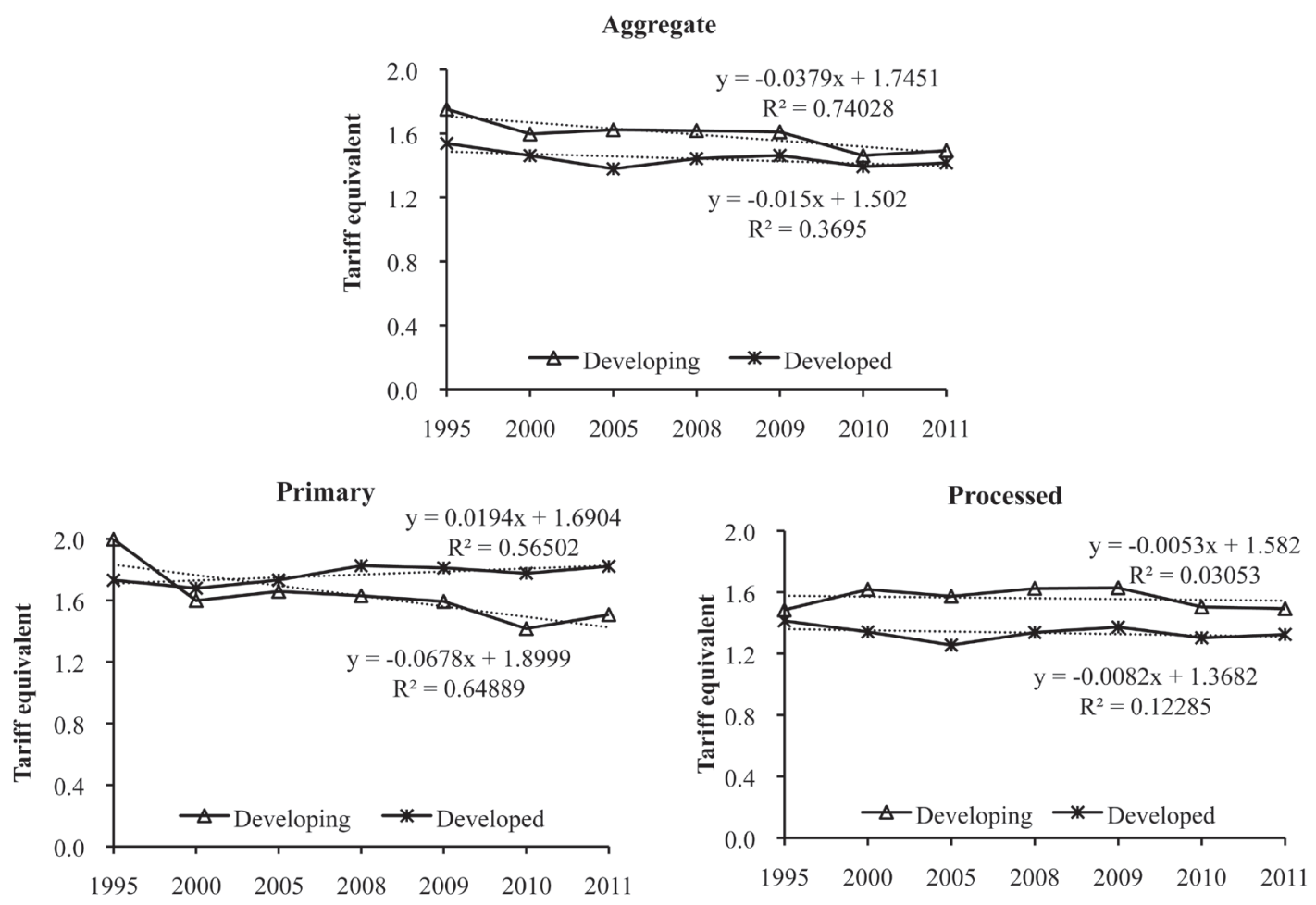

Fig. 3. Weighted average tariff equivalent of China's agricultural trade costs across partners groups and sectors. 


\section{THE DETERMINANTS OF TRADE COST MEASURE}

\section{Empirical specification and data}

Having measured the relative bilateral trade cost for China's agriculture with most of its trading partners, we examine its likely determinants to discern what factors have been driving the evolution of China's agricultural trade costs over time.

The empirical model, which is derived from the following function for trade costs, is widely used in the gravity literature:

$$
\tau_{i j t}=\alpha D i s_{i j}^{\beta} \exp p\left(Z_{i j t} \delta+\varepsilon_{i j t}\right)
$$

where Dis $_{i j}$ denotes the geographical distance between countries $i$ and $j$, which is often measured using "great circle" calculations. $Z_{i j t}$ is a row vector of variables representing the various bilateral frictions that limit the flow of goods between countries $i$ and $j$ and includes familiar standbys in the literature such as the physical distance separating countries. $\varepsilon_{i j t}$ is a normally distributed random error term that has a zero mean and constant variance.

We log-linearize equation (6) and define country $i$ as China. The determinants of trade costs are the same as those in gravity literature and include geographical, cultural and institutional variables. More precisely, our benchmark specification takes the following form:

$$
\begin{aligned}
\ln \tau_{j t}= & \alpha_{t}+\alpha_{j}+\beta \text { lnDist }_{j}+\sigma_{1} \text { Border }_{j}+\sigma_{2} \text { Locked }_{j} \\
& +\sigma_{3} \text { Lang }_{j}+\sigma_{4} \text { RTA }_{j t}+\sigma_{5} \text { WTO }_{j t}+\sigma_{6} \text { Pri }+\varepsilon_{j t}
\end{aligned}
$$

where $\tau_{j t}$ is the relative trade cost facing China's exports to country $j$ in year t, Dist $_{j}$ is the distance between China and its trading partner $j$, Border $_{j}$ is a dummy variable that equals one only if country/region $j$ shares a contiguous border with China (and zero otherwise), Locked $_{j}$ is a dummy variable that takes on the value of one if trading partner $j$ is landlocked, and zero otherwise. All of these variables are proxies for geographical factors that capture the physical transport costs. Lang is a dummy equal to one if country/region $j$ speaks Chinese, and zero otherwise. The variable is used to proxy for cultural linkage and is expected to reduce trade costs as it facilitates communication during economic transactions.

$R T A_{j t}$ is a dummy variable that equals one if countries $j$ and China belong to the same regional trading agreement in year t, and zero otherwise. Herein, we define the regional trading agreement (RTA) to include a free trade agreement, customs union, economic integration agreement and preferential trade agreement. Following the framework of Subramanian and Wei (2007), we define RTAs and the WTO mutually and exclusively to isolate the impact of each, thereby negating possible contamination from the other. Therefore, the dummy related to joint membership in the WTO in our analysis is coded to exclude country pairs belonging to the same RTA. $W T O_{j t}$ takes the value of one if both country $j$ and China are members of the WTO, and they do not share a common RTA in year $t$. The two dummy variables are used as proxies for institutional factors.

The $\alpha_{t}$ and $\alpha_{j}$ terms represent annual dummies and country fixed effects to capture other unobserved timespecific and time-invariant attributes that may determine bilateral trade activity. Recent gravity literature suggests the inclusion of time-varying importer and exporter fixed effects in a panel setting as a consistent alternative to controlling for multilateral resistance (Baier and Bergstrand, 2007; Subramanian and Wei, 2007). However, as the trade cost measure $\tau_{i j}$ has netted multilateral resistance components, time-varying country fixed effects are not required.

\begin{tabular}{|c|c|c|c|c|c|c|}
\hline Variables & Description & Obs & Mean & Std. Dev & Min & Max \\
\hline $\ln \tau$ & Log of trade costs of pooled agricultural products & 809 & 0.78 & 0.37 & -0.35 & 1.75 \\
\hline $\ln \tau$ pri & Log of trade costs of primary agricultural products & 394 & 0.89 & 0.36 & 0.08 & 1.75 \\
\hline $\ln \tau$ pro & Log of trade costs of processed agricultural products & 415 & 0.68 & 0.35 & -0.35 & 1.54 \\
\hline lnDist & Log of distance & 809 & 8.82 & 0.57 & 6.86 & 9.87 \\
\hline Border & Indicator variable for common borders, common border $=1$, otherwise 0 & 809 & 0.07 & 0.25 & 0 & 1 \\
\hline Locked & A landlocked indicator variable, landlocked trading Partner $=1$, otherwise 0 & 809 & 0.10 & 0.31 & 0 & 1 \\
\hline Lang & Indicator variable for common language, common language $=1$, otherwise 0 & 809 & 0.07 & 0.25 & 0 & 1 \\
\hline RTA & Indicator variable taking value 1 if two countries belong to a common RTA & 809 & 0.15 & 0.35 & 0 & 1 \\
\hline WTO & $\begin{array}{l}\text { Indicator variable taking value } 1 \text { if two countries are members of WTO and do } \\
\text { not share a common RTA }\end{array}$ & 809 & 0.56 & 0.50 & 0 & 1 \\
\hline Pri & $\begin{array}{l}\text { Indicator variable for primary agricultural sector, primary sector }=1 \text {, processed } \\
\text { sector }=0\end{array}$ & 809 & 0.49 & 0.50 & 0 & 1 \\
\hline DEVED & $\begin{array}{l}\text { Indicator variable for developed country, developed country=1, developing } \\
\text { country }=0\end{array}$ & 809 & 0.63 & 0.48 & 0 & 1 \\
\hline $\operatorname{Pri}^{*} R T A$ & An interaction term in Pri and RTA & 809 & 0.07 & 0.26 & 0 & 1 \\
\hline $\mathrm{Pri}^{*} W T O$ & An interaction in term Pri and WTO & 809 & 0.27 & 0.45 & 0 & 1 \\
\hline Pri*DEVED & An interaction term in Pri and DEVED & 809 & 0.31 & 0.46 & 0 & 1 \\
\hline
\end{tabular}

Next, we estimate the benchmark specification of

Table 1. Descriptive Statistics of the Data 
equation (8) as derived herein. First, the benchmark equation is applied separately to the primary and processed agricultural sectors to identify evidence of a differential role of the determinants of trade costs. In particular, the adaptation is used to discern whether the effects of the WTO on trade costs differ across sectors. Second, we introduce dummy variables for the developed trading partner $\left(D V E D_{j t}\right)$ to our benchmark specification. $D V E D_{j t}$ equals one only if trading partner $j$ is a developed country/region in year t. The dummy variable is used to test whether trade cost asymmetries of China's agriculture between developed and developing trading partners are found in the trade data. Finally, we interact dummies for joint membership of trading agreements and developed trading partners with the agricultural industry dummy, respectively. The interaction terms allow us to perform specific significance tests, enabling claims about the differences among the above regression coefficients.

The data on geographical and cultural proximity are obtained from the CEPII database. Information regarding WTO and RTA membership status is from the WTO official website. Table 1 summarizes the means, stand- ard deviations and minimums and maximums of the distribution of the dependent and independent variables employed in the estimated models.

\section{Regression results}

The econometric results are displayed in Table 2. Column (1) considers basic regressions with typical gravity-like covariates for pooled agricultural sectors. Columns (2) and (3) consider separately primary and processed agricultural sectors. Columns (4) and (5) add the dummy variables for developed countries/regions to discern whether China's trade costs differ between developed and developing trading partners. Columns (6) through (8) introduce the various interaction terms to perform specific significance tests.

Considering the pooled results (column (1)), we find all the regressors have the expected signs whenever they are significant. The regression explains approximately 86 percent of the trade costs variation. With respect to ranking trade cost determinants, we find that, on average, geographical and cultural factors dominate those of institutions. Distance from China to its trading partners and trading relationships with landlocked coun-

Table 2. Regression of Trade Cost Measure on Observable Trade Cost Proxies

\begin{tabular}{|c|c|c|c|c|c|c|c|c|}
\hline & $\begin{array}{c}(1) \\
\text { Pooled }\end{array}$ & $\begin{array}{c}(2) \\
\text { Primary }\end{array}$ & $\begin{array}{c}(3) \\
\text { Processed }\end{array}$ & $\begin{array}{c}(4) \\
\text { Primary }\end{array}$ & $\begin{array}{c}(5) \\
\text { Processed }\end{array}$ & $\begin{array}{c}(6) \\
\text { Pooled }\end{array}$ & $\begin{array}{c}(7) \\
\text { Pooled }\end{array}$ & $\begin{array}{c}(8) \\
\text { Pooled }\end{array}$ \\
\hline \multirow[t]{2}{*}{ lnDist } & $0.143^{* * *}$ & $0.119 * * *$ & $0.151^{* * *}$ & $0.185^{* * * *}$ & $0.115^{* * *}$ & $0.143^{* * *}$ & $0.070 * * *$ & $0.070 * * *$ \\
\hline & $(0.014)$ & $(0.020)$ & $(0.016)$ & $(0.033)$ & $(0.012)$ & $(0.015)$ & $(0.011)$ & $(0.011)$ \\
\hline \multirow[t]{2}{*}{ Border } & $-0.190 * *$ & $-0.121^{*}$ & $-0.539 * * *$ & 0.135 & -0.000 & $-0.190^{* *}$ & 0.077 & 0.077 \\
\hline & $(0.068)$ & $(0.059)$ & $(0.071)$ & $(0.072)$ & $(0.043)$ & $(0.069)$ & $(0.053)$ & $(0.052)$ \\
\hline \multirow[t]{2}{*}{ Locked } & $0.463^{* * *}$ & $0.386^{* * *}$ & $0.250^{* * *}$ & $0.360 * * *$ & $0.540 * * *$ & $0.462^{* * *}$ & $0.612^{* * *}$ & $0.612^{* * *}$ \\
\hline & $(0.042)$ & $(0.063)$ & $(0.035)$ & $(0.086)$ & $(0.023)$ & $(0.043)$ & $(0.039)$ & $(0.039)$ \\
\hline \multirow[t]{2}{*}{ Lang } & $-0.196 * * *$ & 0.108 & $-0.087 * *$ & $-0.414^{* * * *}$ & $-0.353^{* * *}$ & -0.049 & $-0.262 * * *$ & $-0.262 * * *$ \\
\hline & $(0.060)$ & $(0.147)$ & $(0.029)$ & $(0.078)$ & $(0.045)$ & $(0.124)$ & $(0.053)$ & $(0.052)$ \\
\hline \multirow[t]{2}{*}{$R T A$} & 0.091 & $0.286^{* * * *}$ & -0.104 & $0.286^{* * * *}$ & -0.104 & 0.101 & 0.092 & 0.080 \\
\hline & $(0.079)$ & $(0.069)$ & $(0.071)$ & $(0.069)$ & $(0.071)$ & $(0.080)$ & $(0.093)$ & $(0.094)$ \\
\hline \multirow[t]{2}{*}{ WTO } & 0.051 & $0.270^{* * *}$ & $-0.160^{*}$ & $0.270 * * *$ & $-0.160^{*}$ & 0.048 & 0.051 & 0.056 \\
\hline & $(0.075)$ & $(0.056)$ & $(0.066)$ & $(0.056)$ & $(0.066)$ & $(0.076)$ & $(0.090)$ & $(0.091)$ \\
\hline \multirow[t]{2}{*}{ Pri } & $0.236^{* * *}$ & & & & & $0.235^{* * * *}$ & $0.144^{* * *}$ & $0.142^{* * *}$ \\
\hline & $(0.010)$ & & & & & $(0.021)$ & $(0.015)$ & $(0.025)$ \\
\hline \multirow[t]{2}{*}{ DEVED } & & & & $0.655^{* * *}$ & $-0.217 * * *$ & & -0.005 & -0.008 \\
\hline & & & & $(0.074)$ & $(0.044)$ & & $(0.053)$ & $(0.052)$ \\
\hline \multirow[t]{2}{*}{ Pri*RTA } & & & & & & 0.021 & & 0.024 \\
\hline & & & & & & $(0.036)$ & & $(0.035)$ \\
\hline \multirow[t]{2}{*}{$\operatorname{Pri}^{*} W T O$} & & & & & & 0.006 & & 0.011 \\
\hline & & & & & & $(0.024)$ & & $(0.024)$ \\
\hline \multirow[t]{2}{*}{$P r i * D E V E D$} & & & & & & & $0.145^{* * *}$ & $0.152 * * *$ \\
\hline & & & & & & & $(0.019)$ & $(0.021)$ \\
\hline$N$ & 809 & 394 & 415 & 394 & 415 & 809 & 809 & 809 \\
\hline$R^{2}$ & 0.875 & 0.908 & 0.938 & 0.908 & 0.938 & 0.875 & 0.884 & 0.884 \\
\hline $\operatorname{adj} . R^{2}$ & 0.864 & 0.889 & 0.926 & 0.889 & 0.926 & 0.864 & 0.873 & 0.873 \\
\hline
\end{tabular}

Notes: The dependent variable is the logarithmic tariff equivalent tariff of trade costs $(\sigma=8)$. Estimation is by OLS. Robust standard errors are in parentheses. Country and year fixed effects not reported. *,** and *** indicates significance at the 10,5 and 1 percent levels, respectively. 
tries/regions are all associated with higher inferred trade costs, whereas sharing a land border is related to lower trade costs. Furthermore, a common language is related to lower trade costs as it likely facilitates bilateral transactions and often reflects cultural similarities. For example, common languages reduce China's bilateral trade costs by 18 percent, on average.

Joint membership in a regional trade agreement or in the WTO has no effect on relative bilateral trade costs that display a positive but insignificant coefficient. It implies that increasingly joining regional agreements has not promoted China's integration into the global agricultural trading system, a finding that corresponds to the findings cited in Section 2.3. However, the underlying reason for this result is not clear. In fact, at least from the perspective of trade protection, the actual evidence suggests that the agricultural sector is usually discriminated against and excluded from free trade rules in bilateral and multilateral trade agreements. Indeed, agricultural sectors continue to be a highly protected sector, with average tariffs well above the average for the industrial sector as a whole, and with significant peak tariffs. For example, Switzerland's overall average tariff rate for agricultural products is approximately 130.9 percent and the maximum is 1062 percent. In addition, the use of non-tariff measures has been increasing both in terms of the number of products covered and the number of countries utilizing them (Word bank and IMF, 2008). The coefficient of the dummy for the primary industry is positive and statistically significant throughout, suggesting that China's primary agriculture has trade costs that are 21 percent higher than those of processed agriculture.

To identify evidence of a differential role of the determinants of trade costs, Columns (2) and (3) consider separately the trade costs of primary and processed agricultural sectors. All the determinants of trade costs have the consistent signs whenever they are significant, except for the joint membership dummy for regional trade agreements and the WTO. The joint membership increases China's trade costs of primary agricultural products but has the opposite effect on processed agricultural products, although these institutional coefficients are not always significant. In primary agriculture, for example, trading with WTO member countries results in an increase in trade costs of 24 percent, on average, compared to non-member countries. By contrast, trading processed agricultural products with WTO member countries is associated with lower trade costs, albeit the related coefficient is barely significant (ten percent level). This is tested by introducing the interaction term $\operatorname{Pr}^{*} W_{T T} \mathrm{O}_{j t}$ in column (6). The positive parameter indicates that the joint membership is related to higher trade costs for the primary sector than for the processed sector, although the parameter is not significant. To some extent, the econometric results exceed our expectations; however they do correspond to the findings by Wen et al. (2013), who found that the WTO has a positive effect on trade costs. This result was likely because China's primary agricultural exports are facing an increasing number of unjustifiable non-tariff barriers in the form of quality standards, sanitary and phytosanitary regulations and import inspections and regulations.

Column (4) and (5) add dummy variables for a developed trading partner. The coefficient value on developed country/regions is positive and significant for the primary agricultural sector, suggesting that, after controlling for geographical, cultural and institutional factors, trading relationships involving developed countries/regions are associated with higher trade costs. In the case of processed agriculture, the parameter is negative and significant. On the contrary, the regression results in column (5) suggest that trading processed agricultural products with developed countries/regions is associated with lower trade costs. The fact that heterogeneity exists in trade costs across trading partner groups is further confirmed by introducing the interaction term Pri*DVED $D_{j t}$ (see columns (7) and (8)).

\section{CONCLUSION}

This paper attempts to determine the size of China's agricultural trade costs and the determinants of those trade costs. Answers to these questions have potentially important implications for evaluating China's ability to position its agriculture in global networks of trade and production and for understanding what factors impede its integration.

We began by applying a micro-founded gravity structure developed by Novy (2011) to measure China's bilateral relative to domestic trade costs with a large cross-section dataset for its trading partners. We found China's agricultural trade costs experienced only a modest downward trend in trade costs during our sample period of 1995-2011, although China has pursued export-oriented economic policies in recent years. The trade-weighted average trade cost was still 141 percent on an ad-valorem equivalent basis in 2011, which was far higher than the world average. These results suggest China has considerable scope for further improving its foreign trade environment. Moreover, the trade cost measure shows substantial differences in the levels of integration across sectors and trading partners. China faces stronger protection in its primary agricultural export to developed countries/regions but also faces more trade barriers of processed agriculture from developing countries/regions. On average, China's primary agriculture faces higher trade barriers than processed agriculture.

Furthermore, this paper investigated the determinants of China's agricultural trade costs with gravitytype variables such as geographical factors, cultural linkages and institutional factors. With respect to ranking the trade cost determinants, the econometric results suggest that, on average, geographical and cultural factors seem to dominate those of institutions. The fact that China's participation in multilateral or bilateral trade agreements has not promoted its integration into global agricultural trading system suggests that China's 
policy prescription towards agricultural integration into the global economy should place emphasis on the legacy effect induced by these exogenous conditions. In addition, in line with estimated results of trade costs, the regression results verified the findings that heterogeneity exists in China's agricultural trade costs across sectors and trading partners.

Finally, it should be noted that our findings may have suffered from bias because our data were unevenly spaced annual bilateral trade data and because we estimated China's agricultural trade cost without taking into account the effect of the trade collapse of 2008. To improve our understanding of China's agricultural trade costs and the determinants of these costs, future research should improve data quality and determine the extent to which trade costs varied during the trade collapse crisis.

\section{ACKNOWLEDGEMENTS}

The authors are grateful for funding support from the National Natural Science Foundation of China (71403128, 71333008), the Fundamental Research Funds for the Central Universities of Nanjing Agricultural University (KJQN201563, SK2014037) and A Project Funded by the Priority Academic Program Development of Jiangsu Higher Education Institutions, China (PAPD).

\section{REFERENCES}

Anderson, J. E. and van Wincoop, E. 2003 Gravity with Gravitas: A Solution to the Border Puzzle. American Economic Review, 93: 170-192

Anderson, J. E. and van Wincoop, E. 2004 Trade costs. Journal of Economic Literature, 3: 691-751

Baier, S. L. and Bergstrand, J. H. 2007 Do free trade agreements actually increase members' international trade? Journal of

Table A1. Index of agricultural bilateral trade costs between China and its major trading partners

\begin{tabular}{|c|c|c|c|c|c|c|c|c|c|c|c|c|c|c|c|c|c|c|c|}
\hline & \multicolumn{3}{|c|}{ Primary } & \multicolumn{3}{|c|}{ Processed } & \multicolumn{3}{|c|}{ Aggregate } & & \multicolumn{3}{|c|}{ Primary } & \multicolumn{3}{|c|}{ Processed } & \multicolumn{3}{|c|}{ Aggregate } \\
\hline & 1995 & 2011 & $\Delta \%$ & 1995 & 2011 & $\Delta \%$ & 1995 & 2011 & $\Delta \%$ & & 1995 & 2011 & $\Delta \%$ & 1995 & 2011 & $\Delta \%$ & 1995 & 2011 & $\Delta \%$ \\
\hline AUS & 171 & 120 & 30 & 146 & 114 & 22 & 156 & 113 & 28 & RUS & 223 & 136 & 39 & 1.29 & 135 & -5 & 158 & 134 & 15 \\
\hline AUT & 403 & 293 & 27 & 299 & 199 & 33 & 332 & 220 & 34 & SGP & 165 & 193 & -17 & 103 & 115 & -12 & 119 & 123 & -3 \\
\hline BEL & 282 & 205 & 27 & 209 & 197 & 6 & 233 & 201 & 14 & SVK & 383 & 248 & 35 & 321 & 254 & 21 & 350 & 240 & 31 \\
\hline CAN & 144 & 135 & 6 & 156 & 128 & 18 & 144 & 130 & 10 & SVN & $* *$ & 317 & $* *$ & 442 & 299 & 32 & 484 & 306 & 37 \\
\hline CHE & 389 & 399 & -3 & 231 & 193 & 17 & 267 & 213 & 20 & SWE & 445 & 342 & 23 & 237 & 189 & 20 & 277 & 215 & 22 \\
\hline CHL & 349 & 211 & 40 & 276 & 165 & 40 & 301 & 174 & 42 & TWN & 188 & 173 & 8 & 148 & 130 & 12 & 166 & 144 & 13 \\
\hline CYP & 361 & 501 & -39 & 430 & 316 & 27 & 352 & 348 & 1 & USA & 143 & 118 & 18 & 139 & 111 & 20 & 137 & 108 & 21 \\
\hline $\mathrm{CZE}$ & 311 & 230 & 26 & 267 & 212 & 21 & 286 & 219 & 23 & $\mathrm{ZAF}$ & 211 & 199 & 6 & 279 & 173 & 38 & 233 & 182 & 22 \\
\hline DEU & 205 & 177 & 14 & 145 & 146 & -1 & 165 & 156 & 6 & ARG & 256 & 191 & 25 & 237 & 178 & 25 & 245 & 166 & 32 \\
\hline DNK & 233 & 210 & 10 & 227 & 159 & 30 & 212 & 173 & 18 & BGR & 459 & 334 & 27 & 253 & 249 & 2 & 310 & 276 & 11 \\
\hline $\mathrm{ESP}$ & 267 & 200 & 25 & 214 & 153 & 29 & 236 & 167 & 29 & BRA & 240 & 145 & 40 & 195 & 132 & 32 & 202 & 134 & 34 \\
\hline EST & 498 & 356 & 29 & 402 & 254 & 37 & 443 & 283 & 36 & BRN & $* *$ & $* *$ & $* *$ & 204 & $* *$ & $* *$ & 297 & 320 & -8 \\
\hline FIN & 360 & 249 & 31 & 262 & 234 & 11 & 290 & 232 & 20 & COL & 291 & 321 & -10 & 334 & 277 & 17 & 298 & 293 & ? \\
\hline FRA & 185 & 189 & -2 & 189 & 138 & 27 & 170 & 153 & 10 & & 379 & 268 & 29 & 237 & 250 & -6 & 258 & 256 & 1 \\
\hline GBR & 200 & 201 & -1 & 179 & 147 & 18 & 190 & 161 & 15 & HRV & $* *$ & 310 & $* *$ & 297 & 301 & -1 & 355 & 299 & 16 \\
\hline GRC & 341 & 230 & 33 & 444 & 230 & 48 & 359 & 223 & 38 & IDN & 186 & 134 & 28 & 179 & 128 & 29 & 181 & 130 & 28 \\
\hline $\mathrm{HKG}$ & 111 & 221 & -99 & 71 & 89 & -25 & 82 & 97 & -18 & IND & 336 & 167 & 50 & 222 & 164 & 26 & 260 & 166 & 36 \\
\hline HUN & 443 & 268 & 40 & 330 & 273 & 17 & 374 & 270 & 28 & KHM & 267 & 294 & -10 & 238 & 296 & -24 & 219 & 249 & -14 \\
\hline IRL & 263 & 297 & -13 & 222 & 174 & 22 & 238 & 202 & 15 & & $* *$ & 248 & $* *$ & $* *$ & 264 & $* *$ & $* *$ & 234 & $* *$ \\
\hline ISL & 454 & $* *$ & $* *$ & 257 & 202 & 21 & 308 & 237 & 23 & LVA & $* *$ & 328 & $* *$ & 468 & 251 & 46 & 535 & 276 & 48 \\
\hline ISR & 335 & 244 & 27 & 224 & 178 & 21 & 251 & 197 & 22 & MEX & 270 & 195 & 28 & 275 & 201 & 27 & 274 & 197 & 28 \\
\hline ITA & 263 & 205 & 22 & 232 & 170 & 27 & 240 & 179 & 25 & MLT & $* *$ & 571 & $* *$ & 342 & 403 & -18 & 389 & 447 & -15 \\
\hline JPN & 163 & 201 & -23 & 135 & 139 & -3 & 148 & 152 & -3 & MYS & 142 & 128 & 10 & 91 & 106 & -17 & 117 & 114 & 3 \\
\hline KOR & 183 & 172 & 6 & 141 & 112 & 21 & 159 & 125 & 21 & PHL & 251 & 180 & 28 & 196 & 154 & 21 & 217 & 165 & 24 \\
\hline LUX & 326 & 307 & 6 & 235 & 261 & -11 & 265 & 275 & -4 & ROU & $* *$ & 248 & $* *$ & 393 & 296 & 25 & 451 & 246 & 46 \\
\hline NLD & 219 & 223 & -2 & 164 & 178 & -9 & 185 & 190 & -3 & $\mathrm{SAU}$ & 452 & 352 & 22 & 299 & 190 & 37 & 354 & 209 & 41 \\
\hline NOR & 397 & 261 & 34 & 257 & 167 & 35 & 293 & 186 & 37 & THA & 200 & 118 & 41 & 123 & 128 & -4 & 148 & 119 & 20 \\
\hline NZL & 221 & 178 & 20 & 185 & 129 & 30 & 201 & 141 & 30 & TUN & 418 & $* *$ & $* *$ & $* *$ & 311 & $* *$ & 456 & 328 & 28 \\
\hline POL & 339 & 308 & 9 & 262 & 195 & 26 & 295 & 218 & 26 & TUR & 335 & 264 & 21 & 304 & 219 & 28 & 322 & 234 & 27 \\
\hline PRT & 324 & 261 & 19 & 430 & 207 & 52 & 346 & 223 & 36 & VNM & 231 & 142 & 39 & 150 & 138 & 8 & 188 & 138 & 27 \\
\hline
\end{tabular}

Note: All values are in percent and rounded off to integers. 
international Economics, 71: 72-95

Duan, S. and Grant, J. H. 2012 Agricultural Trade Costs: 19652010. Selected Paper prepared for presentation at the Agricultural \& Applied Economics Association's AAEA Annual Meeting, Seattle, Washington

Fang, H., Peng, B., Feng, Z. and Wu, J. J. 2010 Research on Measurement of Bilateral Costs of International Trade-Based on Revised Gravity Model. Finance \& Trade Economics, 5: $71-76$

Head, K. and Mayer, T. 2000 Non-Europe: the magnitude and causes of market fragmentation in the EU. Weltwirtschaftliches Archiv, 136: 284-314

Head, K. and Ries, J. 2001 Increasing returns versus national product differentiation as an explanation for the pattern of US-Canada trade. American Economic Review, 91: 858876

Jacks, D.S., Meissner, C. M. and Novy, D. 2011 Trade booms, trade busts, and trade costs. Journal of International Economics, 83: 185-201

Novy, D. 2011 Gravity Redux: Measuring International Trade Costs with Panel Data. working paper, University of Warwick

Obstfeld, M. and Rogoff, K. 2001 The six major puzzles in international macroeconomics: is there a common cause? In NBER
Macroeconomics Annual 2000, pp.339-412

Olper, A. and Raimondi, V. 2009 Patterns and determinants of international trade costs in the food industry. Journal of Agricultural Economics, 60: 273-297

Shi, B. Z. 2008 The Measurement of Trade Cost between China and Its Main Trade Partners-Based on the Revised Gravity Model. Journal of International Trade, 11: 24-30

Subramanian, A. and Wei, S. J. 2007 The WTO promotes trade, strongly but unevenly. Joumal of international Economics, 72: $151-175$

Wei, S. J. 1996 Intra-national versus international trade: how stubborn are nations in global integration? NBER Woking Paper, No.5531

Wen, S. M., Zheng, J. and Liu, X. L. 2013 An analysis on China's agricultural bilateral trade costs? 1995-2007. China Agricultural Economic Review, 5: 360-372

Word bank and IMF. 2008 Global monitoring report, 2008. Washington DC: world bank

$\mathrm{Xu}, \mathrm{D}$. Y. and Liang, Q. 2010 The measurement and analysis of China's foreign bilateral trade costs: 1981-2007. The Journal of Quantitative and Technical Economics, 1: 119-127

Xu, T. S., Li, Z. M., Tu, Y. F. and Yu, C. L. 2012 An Estimation of China's Trade Cost for Agricultural Products. Chinese rural economy, 3: 14-24 